\title{
SANKSI PIDANA MATI PELAKU TINDAK PIDANA KORUPSI MELALUI SUDUT PANDANG NORMA-SUBTANTIF DI INDONESIA
}

\author{
Fina Rosalina \\ Fakultas Hukum \\ Universitas Muhammadiyah Jember, Jawa Timur \\ Email : finarosalina09@gmail.com
}

\begin{abstract}
Abstraks
Semangat untuk melakukan pemberantasan tindak pidana korupsi, terlihat melalui dijadikannya sanksi pidana mati menjadi salah satu jenis pidana dalam ketentuan Undang Undang Pemberantasan Tindak Pidana Korupsi (UU PTPK). Sanksi pidana mati tersebut merupakan gradasi tertinggi yang diberikan atas pemberatan terhadap unsur "keadaan tertentu". Namun demikian, sampai dengan saat ini, kendati unsur "keadaan tertentu" telah terpenuhi, masih belum terdapat realisasi penerapan sanksi pidana mati. Terdapat kelemahan yurudis (subtantivenorm) dalam keberlakuan UU PTPK. UU PTPK sebagai sub-sistem tidak berjalan linear terhadap undang undang lain yang pada dasarnya masih memiliki keterkaitan. Hal lain, terdapat norma kabur (vague norm) atas karakteristik unsur "keadaan tertentu" sehingga menyebabkan ketidakpastian hukum yang menjadi dasar sulitnya diterapkan sanksi pidana mati pada pelaku korupsi. Hal tersebut cukup menjadi dasar pembuktian bahwa Negara Indonesia belum siap menerapkan sanksi pidana mati sebagai gradasi tertinggi atas sanksi pemidaan terhadap pelaku korupsi.
\end{abstract}

Kata Kunci : sanksi pidana mati, tindak pidana korupsi, sistem pemidanaan.

\begin{abstract}
The spirit to eradicate corruption can be seen through the making of death penalty Sanctions as a type of crime in the provisions of the Corruption Eradication Act. death penalty Sanctions is the highest gradation given for the weighting of elements of "emergency conditions". However, up to now, although the elements of "emergency conditions" have been met, there is still no realization of the implementation of death penalty Sanctions. There is a juridical weakness (substantive-norm) in the application of the Corruption Eradication Act. The Corruption Eradication Act as a sub-system does not run linearly with other laws which are basically still related. Another thing, there is a vague norm on the characteristics of elements of "emergency conditions" causing legal uncertainty
\end{abstract}


which is the basis for the difficulty of applying death penalty Sanctions to corruption perpetrators. This is sufficient to prove that the State of Indonesia is not ready to apply death penalty Sanctions ctions as the highest gradation of criminal sanctions against perpetrators of corruption.

Keywords : death penalty sanctions, corruption crime, punishment system.

\section{PENDAHULUAN}

\section{A. Latar Belakang}

Tindak Pidana Korupsi merupakan kejahatan dengan aspek konsekuensi yang begitu luas. Konsekuensi tersebut dapat meliputi rendahnya pertumbuhan perekonomian, buruknya sistem kelembagaan, ketimpangan pendapatan dalam masyarakat, hingga pada tingginya tingkat kemiskinan dalam suatu negara. ${ }^{1}$ Hal lain, terdapat banyak sekali dimensi yang merupakan turunan atas tindak pidana korupsi diantaranya kejahatan yang bersifat teroganisir, kejahatan kerah putih, kejahatan ekonomi, serta kejahatan politik. Maka tidak menjadi hal yang berlebihan bila tindak pidana korupsi digolongkan sebagai extra ordinary crime. ${ }^{2}$

Tindak pidana korupsi sebagai extra ordinary crime melahirkan criminal policy, yang beberapa diantaranya termuat dalam Undang Undang No 31 Tahun 1999 jo Undang Undang No 20 Tahun 2001 Tentang Pemberantasan Tindak Pidana Korupsi (Selanjutnya UU PTPK). Tindak Pidana korupsi dalam keadaan tertentu merupakan salah satu criminal policy yang dianut dalam UU PTPK. Konteks "keadaan tertentu" dijelaskan melalui ketentuan Pasal 2 ayat (2) UU PTPK sebagai pemberatan pidana bilamana perbuatan korupsi tersebut dilakukan terhadap dana penanggunalangan bencana nasional, penanggulangan kerusuhan sosial meluas, penanggulangan krisis ekonomi, penanggulangan keadaan biaya dan pengulangan tindak pidana korupsi.

Sanksi pidana mati yang dijatuhkan kepada koruptor yang melakukan tindak pidana dalam keadaan tertentu, diklasifikasikan sebagai pemberatan tindak

\footnotetext{
${ }^{1}$ Komisi Pemberantasan Tindak Pidana Korupsi, Dampak sosial Korupsi (Jakarta: Direktorat Pendidikan Dan Pelayanan Masyarakat Kedeputian Bidang Pencegahan, 2016) at 27.

2 Ervanda Rifqi Priambodo, et al, "Mengapa Korupsi Sulit Diberantas" (2021) Jurnal Ilmu Hukum Humaniora dan Ilmu Politik, Volume 1, Issue 1, September 2020, online: <https://dinastirev.org/JIHHP> diunduh pada tanggal 03 Juli $2021 \mathrm{Pkl} 05.32$.
}

150 HUKMY|Jurnal Hukum 
pidana. Pemberatan sanksi terhadap pelaku tindak pidana korupsi, lahir atas semangat kuat para pembentuk undang undang dalam hal pemberantasan tindak pidana korupsi. Semangat pemberantasan tindak pidana korupsi tersebut dapat dilihat pula melalui animo masyarakat untuk mendukung diberlakukan sanksi pidana mati bagi koruptor. Bahkan, terkait sanksi pidana mati, masyarakat menginginkan untuk memperluas konteks "keadaan tertentu" dalam ketentuan Penjelasan Pasal 2 ayat (2) UU PTPK dengan mengajukan judicial review kepada Mahkamah Konstitusi (selanjutnya disebut MK). Meskipun dalam kenyataanya judicial review tersebut ditolak oleh MK, namun demikian upaya-upaya tersebut harus dibaca sebagai keinginan kuat Bangsa Indonesia untuk memberantas tindak pidana korupsi dari bumi Indonesia.

Berbalik dari ketentuan tersebut, dalam praktiknya, sampai dengan saat ini belum ada pelaku korupsi di Indonesia yang dikenakan sanksi pidana mati. ${ }^{3}$ Padahal terdapat fakta hukum yang telah bersesuaian dengan unsur "keadaan tertentu" sebagaimana dipersyaratkan dalam ketentuan Pasal 2 ayat (2) UU PTPK. Misal saja dapat dicontohkan tindak pidana korupsi yang dilakukan secara berulang oleh Muhammad Tamzil, Mantan Bupati Kudus. Muhammad Tamzil melakukan korupsi terhadap dana bantuan dan sarana pendidikan 2004-2005, tak lebih dari 3,5 Tahun, Muhammad Tamzil terjerat kembali dalam kasus rusuan jual beli jabatan. ${ }^{4}$ Atas permasalahan hukum tersebut Tamzil hanya dikenakan pidana penjara selama delapan tahun dan denda 250 juta subsider empat bulan penjara.

Bahkan yang terbaru, diatas riuhnya bencana global yang diakibat virus covid-19, Jualiari Batubara, mantan Menteri Sosial melakukan kejahatan tindak pidana korupsi atas dana bantuan sosial penanggulangan covid-19.5 Terhadap Juliari Batubara hanya didakwa dengan tindak pidana suap sebagaimana diatur dalam Pasal

3 Edi Yunara, Korupsi dan Pertanggungjawaban Pidana Korporasi (Bandung: Citra Aditya Bakti, 2012) https://jurnal.ar-raniry.ac.id/ diunduh pada tanggah 02 Juli 2021 Pkl 20.22.

4 Bupati Kudus Mengulang Korupsi Cabut Saja Hak Politik Korupsi, by Metro Pekan Baru (2021) https://metropekanbaru.com/icw-bupati-kudus-mengulang-korupsi-cabut-saja-hak-politik-koruptor/ diunduh tanggal 21 juni $2021 \mathrm{Pkl} 20.12$.

5 “KPK Tetapkan Mensos Juliari Batubara Tersangka Kasus Dugaan Suap Bansos" (2021) Kompas, online: <https://nasional.kompas.com/read/2020/12/06/02081481/kpk-tetapkan-mensos-juliaribatubara-tersangka-kasus-dugaan-suap-bansos> diunduh tanggal 22 juni 2021 Pkl 07.22. 
12 huruf a UU PTPK. ${ }^{6}$ Hal mana diketahui Virus Covid-19 telah digolongkan dalam Pandemi, ${ }^{7}$ dan ditetapkan sebagai bencanan nasional melalui Peraturan Presiden No 12 Tahun 2020 Tentang Penetapan Bencana Nonalam Penyebaran Corona Virus Disease 2019 (Covid-19) Sebagai Bencana Nasional. Namun terhadap Menteri Sosial Juliari Batubara tidak didakwa menggunakan ketentuan Pasal 2 ayat (2) UU PTPK.

Terlepas perdebatan panjang antara pro pidana mati (retensionis) dan kontra pidana mati (abolisionis), Hukuman mati bukanlah sebagai sanksi yang bertentangan dengan UUD Negara RI Tahun 1945. Hal tersebut telah diperkuat melalui Putusan MK No .2-3/PUU-V/2007. Namun demikian, hukuman mati harus bersifat "the most serious crimes" 8 Noodrecht (hukuman darurat) harus dijadikan landasan hukuman mati terhadap pelaku kejahatan yang membahayan masyarakat. ${ }^{9}$

Penetapan sanksi pidana mati dalam ketentuan UU PTPK, pada dasarnya telah diwanti-wanti oleh Panitia Khusus yang membahas RUU Pemberantasan Korupsi agar bilamana ditetapkan sebagai salah satu sanski pidana, harus ditetapkan secara tepat. Sanksi pidana mati yang diancamkan tapi tidak pernah diterapkan justru akan merendahkan hukum pidana sendiri. ${ }^{10}$ Jeremy Bentham melarang penggunaan sanksi yang bersifat groundless, needless, unprofitable dan inefficacious. ${ }^{11}$ Herbert L. Packer menyebutkan sanksi pidana akan bersifat prime threatener bilamana sanksi tersebut digunakan secara paksa (coercively). ${ }^{12}$

Sanksi pidana mati dalam UU PTPK merupakan kesatuan dan tidak terlapas dari sistem pemidanaan secara umum. Muzakir mengartikan sitem pemidanaan menggunakan istilah sudut pandang fungsional dan sudut pandang norma-

\footnotetext{
6 Juliari Batubara terima Rp32 Miliar ini dakwaan Jaksa (2021) https://kabar24.bisnis.com/read/20210421/16/1384092/wow-juliari-batubara-terima-rp32-miliar-inidakwaan-jaksa diunduh pada tanggal 01 Juni $2021 \mathrm{Pkl} 20.23$.

7 Kamus Bahasa Indonesia (Jakarta: Pusat Bahsa Departemen Pendidikan Indonesia, 2018) at 1116 mengartikan pandemi sebagai wabah yg berjangkit serempak di mana-mana yg meliputi daerah geografi yg luas.

8 Roby Satya Nugraha, "Penjatuhan Hukuman Mati Terhadap Pelaku Tindak Pdiana Korupsi Berdasarkan Pasal 2 Ayat 2 Undang-Undang PTPK” (2020) Volume 06, Nomor 02 Pakuan Law Review.p 59-73.

${ }^{9}$ Wirjono Prodjodikoro, Asas-asas Hukum Pidana Indonesia (Bandung: PT. Eresco, 1989) at 176-177.

10 Risalah Rapat Panitia Khusus Rancangan Undang Undang Pemberantasan Tindak Pidana Korupsi, (Rapat Kerja Ke-2), by Menteri Kehakiman dan Jajarannya (1999) at 103-104.

${ }^{11}$ Barda Nawawi Arief, Bunga Rampai Hukum Pidana (Bandung: Citra Aditya Bakti, 1996) at 2.

12 Herbert L Packer, The Limits of the Criminals Sanctions (California: Stanford University Press, 1968) at 87.
}

\section{HUKMY | Jurnal Hukum}


subtantif. ${ }^{13}$ Sudut pandang fungsional diartikan sebagai konkretisasi peraturan perundang-undangan sehingga seseorang dapat dijatuhi sanksi. Hal mana secara fungsional sistem pemidaan terbagi atas subsistem pelaksanaan pidana, sub sistem subtantif/materiil, dan sub sistem formil. ${ }^{14}$ Sedangkan sudut pandang normasubtantif terbagi atas sistem hukum materiil (pemberian/penjatuahan sanksi) dan pelaksana pidana. 15

\section{B. Rumusan Masalah}

Penelitian ini dilakukan dengan mengkoreksi penerapan sanksi pidana mati dalam UU PTPK melalui sudut pandang Norma-Subtantif, baik secara internal (keberlakuan hukuman mati dalam UU PTPK) maupun eksternal (keberlakuan sistem pemidaan dan hal lain yang terkait diluar keberlakuan UU PTPK). Atas dasar tersebut, maka disusun sub pertanyaan sebagai berikut: 1. Bagaimana Karakteristik sanksi pidana mati dalam sistem hukum Indonesia ?; 2. Bagaiamana pengaturan Norma-Subtantif Sanksi Pidana Mati dalam UU PTPK ?.

\section{Motode Penelitian}

Metode penelitian yang digunakan untuk menjawab isue hukum yang diangkat adalah metode penelitian hukum. Adapun type penelitian yang digunakan adalah yuridis normatif (legal research) yang bersifat deskriptif analitis. ${ }^{16}$ Melalui metode penelitian yuridis normative, diharapkan dapat ditemukan faktor-faktor yang mempengaruhi keberlakuan hukuman mati di Indonesia dengan cara mengumpulkan, menyusun, menjelaskan dan menganalisis peraturan, keterkaitannya dengan teori yang diangkat serta praktek keberlakuan hukuman mati di Indoneisa. ${ }^{17}$

Cohen menyebutakan terdapat beberapa pendekatan yang digunakan

13 Mudzakkir, Perencanaan Pembangunan Hukum Nasional Bidang Hukum Pidana Dan Sistem Pemidanaan (Politik Hukum Dan Pemidanaan) (Departemen Hukum dan Hak Asasi Manusia Badan Pembinaan Hukum Nasional, 2008) at 87.

14 Ibid.

15 Ibid.

161 Ronny Hanitjo Soemitro.Metode Penelitian Hukum Dan Jurimetri, (Jakarta: Ghalia Indonesia, 1990),Hlm 35

171 Ronny Hanitjo Soemitro, .Metode Penelitian Hukum Dan Jurimetri, (Jakarta: Ghalia Indonesia, 1990), (Jakarta: Ghalia Indonesia, 1990) at 35. 
dalam penelitian yuridis normatif, beberapa diantaranya yaitu: Pendekatan analitis, pendekatan perbandingan/komparatis, pendekatan konseptual, pendekatan peraturan perundang-undangan, pendekatan kasus, pendekatan sejarah, dan pendekatan filosofi. ${ }^{18}$ Namun demikian dalam penelitian ini hanya terbatas menggunakan pendekatan pendekatan perundang-undangan, pendekatan konseptual, dan pendekatan kasus.

Keberfungsian pendekatan perundang-undangan dalam penelitian ini adalah untuk menemukan konsistensi, kedudukan/hierarki, serta keberlakuan asas dalam undang undang yang diteliti. ${ }^{19}$ Adapun peraturan perundangundangan : KUHP, UU PTPK, Undang Undang Keuangan Negara, ${ }^{20}$ Undang Undang Perbendaharaan Negara. ${ }^{21}$ Pendekatan konseptual digunakan untuk menemukan jawaban isue hukum melalui pandangan para ahli hukum dan doktrin yang berkembang dalam ilmu hukum. ${ }^{22}$ Adapun konsep yang digunakan dalam penelitian ini adalah konsep hukuman mati, konsep keuangan dan kerugian keuangan negara. Pendekatan kasus adalah menggunakan ratio decidendi dan reasoning seorang hakim dalam melahirkan suatu putusan hukum ${ }^{23}$ Adapun putusan yang dijadikan pendekatan dalam penelitian ini adalah Putusan MK Nomor 2-3/PUU-V/2007.

\section{PEMBAHASAN}

\section{Karakteristik Sanksi Pidana Mati dalam Sistem Hukum Indonesia.}

Eksistensi penerapan sanksi pidana mati di Indonesia masih termuat dalam beberapa peraturan Perundang-undangan. KUHP mengakui adanya hukuman mati dalam beberapa delik diantaranya : (i). Makar terhadap Presiden dan Wakil Presiden (Psl 104); (ii). Membujuk negara asing untuk bermusuhan atau berperang (Psl 111); (iii). Melakukan perbantuan kepada musuh pada saat berperang (Psl 124 ayat (1)); (iv). Menganjurkan atau menyebabkan terjadinya huru-hara (Psl 124 bis); (v).

18 Mei Susanto \& Ajie Ramdan, Kebijakan Moderasi Pidana Mati (Kajian Putusan Mahkamah Konstitusi Nomor 2-3/PUU-V/2007) (Jurnal Yudisial, 2017) at 193-157.

${ }^{19}$ Peter Mahmud Marzuki, Penelitian Hukum (Jakarta: Kencana Predana Media Group, 2005) at 96.

20 Undang Undang No 17 Tahun 2003 Tentang Keuangan Negara

${ }^{21}$ Undang Undang no 1 Tahun 2004 Tentang Perbendaharaan Negara

22 Ibid at 137.

${ }^{23}$ Ibid at 97.

\section{HUKMY|Jurnal Hukum}


Perencanaan makar terhadap Kepala Negara sahabat yang berakibat mati (Psl 140 ayat (3)); (vi). Pembunuhan berencana (Psl 340 ayat (3)); (vii). Pencurian dengan kekerasan yang menyebabkan luka berat atau kematian (Psl 365 ayat (4)); (viii). Pembajakan laut, pesisir, atau sungai yang menyebabkan kematian (Psl 444); (ix). Kejahatan penerbangan atau terhadap prasaranan penerbangan (Psl $479 \mathrm{k}$ ayat (2) dan Psl 479 o ayat (2))

Terdapat pula beberapa undang undang khusus yang menetapkan sanksi pidana mati diantaranya adalah Undang Undang Narkotika, Undang Undang Tentang psikotropika, Undang-Undang Tentang Pengadilan Hak Asasi Manusia, Undang Undang tentang Pemberantasan Tindak Pidana Korupsi, Undang-Undang tentang Pemberantasan Tindak Pidana Terorisme, UU Darurat Nomor 7 Tahun 1955 Tentang Pengusutan, Penuntutan, dan Peradilan Tindak Pidana Ekonomi, dsb.

Kendati pidana mati masih diberlakukan di Indonesia, namun perdebatan penerapan pidana mati di Indonesia masih menghadirkan pro dan kontra. Terdapat beberapa dasar yang menjadi pertimbangan pidana mati seharusnya tidak dijadikan salah satu jenis pidana yang diakui di Indonesia, beberapa diantaranya yaitu: Pertama, Psala 28A, Pasal 28I ayat (1) dan 28I ayat(4) mengamanatkan bahwa hak untuk hidup (right to life) adalah hak yang tidak dapat dikurangi dan dilindungi oleh negara. pengakuan pidana mati oleh negara adalah pengingkaran kewajiban negara untuk melindungi hak hidup warganegaranya.

Kedua, sanksi pidana mati yang bersumber kepada Kitab Undang Undang Hukum Pidana atau wetboek van strafrech disahkan pada tanggal 1 Januari 1981 dan merupakan warisan Belanda yang sudah tidak layak lagi untuk digunakan. ${ }^{24}$ Bahkan Sejak tahun 1870, Negara Belanda telah menghapuskan pidana mati dalam sistem pemidanaan di negaranya.

Ketiga, Sanksi Pidana mati memiliki tujuan yang kontra produktif dengan Tujuan sistem pemasyarakatan yang dianut di Indonesia yaitu memperbaiki pelaku kejahatan agar dapat diterima kembali oleh masyarakat, ${ }^{25}$ yang kemudian selanjutnya

\footnotetext{
24 JE Sahetapy, Pidana Mati dalam Negara Pancasila (Bandung: P.T. Citra Aditya Bakti, 2007) at 14.

25 Lihat ketentuan Pasal 2 UU Pemasyarakatan
} 
dapat berintegrasi kembali sebagai anggota masyarakat. ${ }^{26}$ Penghilangan nyawa terpidana menyebabkan tidak terpenuhinya asas integrasi sebagaimana tujuan yang hendak di capai dalam tujuan Lembaga Pemasyarakatan.

Keempat, Tidak dapat diperbaikinya putusan pengadilan tentang hukuman mati seorang terpidana yang didalam putusan tersebut bilamana terdapat kesalahan/cacat hukum. Beccaria, mencontohkan pada abad ke-18 terhadap khasus pidana mati Jean C'allas di Perancis yang dituduh membunuh putera dari seorang raja dan ia dipidana mati. Namun ternyata, pelaku pembunuhan bukan Jean C'allas, sedang hukuman mati telah dijatuhkan. ${ }^{27}$ Prof.Sudarto, menyebutkan bahwa kemungkinan untuk memperbaiki (irrevocable) pelaku kejahatan tidak dapat dilakukan bila sanksi pidana mati dilakukan, hal mana kekeliruan dalam suatu peradilan bisa saja terjadi, selanjutnya Prof Sudarto menyebutkan bahwa tidak terdapat manfaat atas diberlakukaanya hukuman mati. ${ }^{28}$

Kelima, Akar dari sanksi pidana mati adalah melegitimasi pembalasan demdam sebagaimana pengakuan dalam teori retributif. Teori retributif dalam perkembangannya telah ditinggalkan dan mulai beralih kepada metode treatment. Gramatika Menyebutkan pemidanaan seharusnya diarahkan kepada pelaku kejahatan bukan kepada perbuatannya. Metode treatment berkembang pada aliran positifis ini memiliki gagasan berupa perawatan (treatment) dan perbaikan (rehabilitasi) kepada pelaku kejahatan

Beberapa dasar alasan yang digunakan oleh kaum kontra pidana mati (abolisionis) untuk melakukan penghapusan hukuman pidana mati di Indonesia, dijawab oleh kaum pro pidana mati (retensionis) sebagai berikut: Pertama, terkait hukuman mati yang melanggar hak asasi untuk hidup (the right to life), dijelaskan oleh kaum pro pidana mati (retensionis) bahwa HAM yang dianut di Indonesia, adalah HAM dengan Pembatasan. Hal tersebut diperkuat melalui ketentuan Pasal 28J ayat (2) UUD Negara RI Tahun 1945 yang menyebutkan bahwa "setiap orang wajib tunduk kepada pembatasan yang ditetapkan dengan undang-undang”. Pembatasan dalam ketentuan

\footnotetext{
${ }^{26}$ Lihat ketentuan Pasal 3 UU pemasyarakatan

27 Efryan R T Jacob, Pelaksanaan Pidana Mati Menurut Undang-Undang Nomor 2/Pnps/19641 (Lex Crimen, 2017) at 99-100.

28 Djoko Prakoso \& Nurwachid, Studi Tentang Pendapat-Pendapat Mengenai Efektivitas Pidana Mati di Indonesia Dewasa Ini (Jakarta: Ghalia Indonesia, 1984) at 11.
} 
pasal tersebut dikenal dengan dengan istilah kewajiban asasi. kewajiban asasi membebankan seseorang untuk melaksanakan pembatasan yang diberikan oleh undang undang atas dasar pertimbangan moral, nilai agama, serta ketertiban umum. Pelanggaran atas pembatasan yang ditetapkan oleh undang undang merupakan pelanggaran atas kewajiban asasi itu sendiri.

Kedua, Terkait KUHP sebagai warisan peninggalan kolonial Belanda, sedangkan Belanda sudah tidak menggunakan hukuman mati dalam hukum pidananya. Andi Hamzah menyebutkan bahwa Indonesia dengan karakter geografis ribuan pulau dengan keanekaragaman suku bangsa, tidak dapat dipersamakan dengan Negara Belanda dengan keadaan geografis dengan luas wilayah yang dominan lebih sempit dari Indonesia. Keadaan geografis dengan multi budaya memerlukan sanksi pidana yang relatif lebih berat. ${ }^{29}$

Hukuman mati pada dasarnya telah diakui oleh masyarakat hukum adat di Indonesia, misal saja masyarakat Minangkabau yang memberlakukan hukum membalas bagi seorang pembunuh. Kalimantan tenggara dikenal dengan hukuman mati dengan ditenggelamkan bagi siapa yang memberikan sumpah palsu. Aceh mengenal hukuman mati bagi yang melanggar hukum Islam yang dilakukan dengan cara menuangkan timah panas, mengiris leher, dijadikan mangsa harimau, dan sebagainya. ${ }^{30}$ Beberapa agama yang ada di Indonesia mengakui keberlakuan hukum mati, contohnya Agama Islam sebagai agama terbesar di Indonesia, dalam surah AlBaqarah: 178 tentang hukum qishaash, menyebutkan bahwa "Hai orang-orang yang beriman, diwajibkan atas kamu qishaash berkenaan dengan orang-orang yang dibunuh..."31 Umat kristiani meskipun mengutamakan memaafkan dengan cinta kasih, ${ }^{32}$ namun umat kritiani mengenal hukuman mati melalui Kitab Taurat dalam Perjanjian Lama. Kitab Taurat perjanjian lama memberikan sanksi mati terhadap perzinahan atau terhadap saksi yang memberikan persaksian palsu. ${ }^{33}$ Hal lain

\footnotetext{
${ }^{29}$ Andi Hamzah, Perbandingan Hukum Pidana Beberapa Negara (Jakarta: Sinar Grafika, 2008) at 11.

30 Yohanes S Lon, "Penerapan Hukuman Mati di Indonesia dan Implikasi Pedagogisnya" Sarana Komunikasi Dosen dan Mahasiswa Volume 14, Nomor 12020 - CC-BY-SA 4.0 License Kertha Wicaksana at 50.

${ }^{31}$ Muhammadiah, "Pidana Mati Menurut Hukum Islam Dan Hukum Positif Di Indonesia" (2019) Volume XI, No. 1 Komunike at 33.

32 Lihat Yohanes 8:11

33 Lihat Ulangan 9:15-21
} 
penjatuhan hukuman mati diakui oleh Rasul Paulus untuk dijatuhkan oleh Negara bilamana hal tersebut diperlukan. ${ }^{34}$

Beberapa dasar tersebut, melalui hukum adat ataupun hukum agama yang berlaku di Indonesia, maka tidak sepenuhnya dibenarkan bahwa hukum mati merupakan warisan Kolonial Belanda. Hal mana diketahui hukum adat (kebiasaan) maupun hukum agama sudah ada terlebih dahulu dari hukum yang dibuat oleh Belanda pada saat itu.

Ketiga, metode treatment yang seharusnya diterapkan dalam Lembaga Pemasyaraktan pada perkembangannya mendapatkan banyak sekali kritik, beberapa diantaranya dapat disebutkan sebagai berikut; 35

a. Metode memperbaiki (treatment) masih sangat sedikit digunakan oleh beberapa negara dikarenakan ketidak tersediaan fasilitas untuk melakukan metode tersebut.

b. Metode rehabilitasi melahirkan tirani individu dan penolakan HAM. Hal tersebut dikarenakan tidak terdapat sebuah kepastian waktu kapan seseorang dengan metode treatment dan rehabilitasi akan sembuh dari penyakitnya. Bilamana penyakit tersebut dirasa belum dapat disembuhkan, maka metode treatment dan rehabilitasi akan diperpanjang, dimana hal tersebut melanggar HAM.

c. metode rehabilitasi sulit untuk dapat diterapkan terhadap seseorang yang memiliki sikab anti sosial.

Keempat, terkait kesanksian terhadap seorang hakim yang mungkin bisa membuat kesalahan dalam pengambilan keputusan pengadilan. Kaum pro pidana mati (retensionis) menyebutkan bahwa statement tersebut bertentangan dengan asas Res Judicata Pro Veritate Habetur yang artinya "putusan hakim harus dianggap benar". Putusan hakim yang dijatuhkan dengan irah-irah "Demi Keadilan Berdasarkan Ketuhanan Yang Maha Esa", harus dianggap benar menurut hukum. Putusan seorang hakim yang dianggap benar tersebut akan berubah sampai ada putusan pengadilan lain yang menganulirnya. ${ }^{36}$ Kelima, tentang hukuman mati yang menitik beratkan pada teori pembalasan, hal tersebut disanksikan oleh kaum retentionis bahwa sifat

\footnotetext{
${ }^{34}$ Lihat Roma 13:1-5

35 dalam putusan Nomor 2-3/PUU-V/2007, by Dr Mahmud Mulyadi, SH, M Hum.

36 Sudikno Mertokusumo \& Pitlo, Bab Bab Tentang Penemuan Hukum (Jakarta: PT Citra Aditya Bakti, 2013) at 7.
}

158 HUKMY|Jurnal Hukum 
hukuman mati adalah pemberian hukuman yang proporsional dengan perbuatan pelaku (balancing justice),

Sanksi hukuman mati menitik beratkan kepada perlindungan masyarakat dan individu, bukan berakar pada falsafah balas dendam. Penjatuhan hukuman mati harus tetap mempertimbangakan hal-hal berupa: Tidak terdapatnya tekanan terhadap pelaku kejahatan (free will), moral pelaku kejahatan (blameworthiness), unsur kesalahan (mens rea) dan kemampuan bertanggungjawab (responsibility) ${ }^{37} \mathrm{Hal}$ tersebut tentu saja berbeda dengan tujuan teori pembalasan yang tidak menitik beratkan kepada kesejahteraan masyarakat (perlindungan indovidu) melainkan murni semata mata untuk pembalasan. ${ }^{38}$

Pro dan Kontra keberlakuan pidana mati di Indonesia, sebagaimana disebutkan diatas, harus sudah dirampunkan, karena secara yuridis, berdasarkan Putusan MK Nomor 2-3/PUU-V/2007, menyebutkan bahwa sanksi pidana mati diakui sebagai salah satu jenis sanksi pidana yang tidak bertentangan dengan Pancasila maupun UUD Negara RI Tahun 1945.

Namun demikian, terdapat 4 perbedaan pendapat (disenting opinion) atas putusan yang menyatan hukuman mati tidak bertentangan dengan UUD Negara RI Tahun 1945. ${ }^{39}$ Hal tersebut menggambarkan bahwa memang, perdebatan penerapan sanksi pidana mati berjalan dengan sangat alot.

Guna menetralkan ketimpangan atas perdebatan sanksi pidana mati tersebut, MK memberikan petunjuk untuk menerapkan kriteria-kriteria terntentu sebelum dapat dilaksanakan sanksi pidana mati melalui Putusan MK Nomor 2-3/PUU-V/2007. Terdapat gradasi berat-ringan (strafmaat) dan bentuk pengenaan sanksi (strafmodus) dalam menjatuhkan sanksi pidana mati. Penjatuhan pidana mati harus dipertimbangkan secara hati-hati. Perlu mempertimbangkan aspek moral edukatif atas penjatuhan sanksi pidana mati. Terdapat dua adagium yang digunakan MK dalam hal ini yaitu "poena ad paucos, metus ad omnes perveniat" (penjatuhan pidana sebagai contoh bagi yang lain) dan "non alio modo puniatur aliquis, quam secundum quod se

\footnotetext{
37 Pertimbangan Hakim dalam Putusan Nomor 2-3/PUU-V/2007

38 Barda Nawawi Arief, Masalah Pemidanaan Sehubungan dengan Perkembangan Delik-delik Khusus Dalam Masyarakat Modern (Bandung: Banacipta, 1982) at 17.

39 Nata Sukam, "Bangun Eksistensi Pidana Mati Dalam Sistem Hukum Indonesia" (2014) Universitas Atma Jaya Yogyakarta Fakultas Hukum Jurnal Ilmiah at 11.
} 
habet condemnation" (seseorang tidak boleh dihukum dengan hukuman yang tak sebanding dengan perbuatannya).

Hal lain terdapat kriteria tertentu agar pidana mati dapat dijatuhkan. Beberapa diantaranya yaitu penerapan pidana mati hanya diberlakukan kepada perbuatan hukum yang bersifat pemberatan (gekwalificeerd delicten) atau terhadap tindak pidana yang bersifat khusus (special carakteristic). Catatan penting bahwa, hukum pidana pada dasarnya dibuat untuk melanggar HAM, maka harus berhati-hati dalam pelaksanaanya. ${ }^{40}$ Terkait sanksi pidana mati, kehati-hatian tersebut dengan cara memperhatikan dengan hal berikut ini : ${ }^{41}$

a. Menjadikan sanksi pidana mati sebagai aternatif sanksi, bukan sebagai pidana pokok;

b. Sanksi pidana mati dapat dirubah menjadi saksi pidana seumur hidup atau sanksi penjaran selama 20 tahun bilaman dalam masa percobaan 10 tahun terpidana berkelakuan baik;

c. Pidana mati terhadap perempuan hamil dilakukan setelah perempuan tersebut melahirkan, sedang kepada seseorang dengan gangguan jiwa maka ditunggu terlebih dahulu sampsi dengan seseorang gangguan jiwa tersebut sembuh.

Memberikan waktu tunggu kepada terpidana menunjukan bahwa, keputusan hakim bukan merupakan keputusan final. Penulis berpendapat, konteks menunggu waktu 10 tahun bagi terpidana, memberikan ketidakpastian dan berpotensi lahirnya pelanggaran HAM bagi terpidana. Hal tersebut dikarenakan, bilamana ternyata dalam waktu 10 tahun LAPAS dan Hakim Pengawas berpendapat bahwa tidak terdapat perubahan kearah yang lebih baik terhadapt terpidana, maka selain diterapkan sanksi hukuman mati pagi terpidana, terpidana juga merasakan kesengsaraan dalam tahanan selama 10 tahun. Sanksi hukuman mati merupakan gradasi tertinggi dalam strata sanksi pidana, maka selayaknya tidak perlu dibebankan sanksi pidana yang lainnya.

Namun demikian, upaya-upaya mempersulit terlaksananya sanksi pidana mati di Indonesia harus diapresiasi sebagai jalan tengah yang diambil oleh MK atas pro dan kontra sanksi pidana mati yang telah terjadi. Mei Susanto menggunakan istilah

40 dalam Risalah Rapat Panitia Khusus Rancangan Undang Undang Pemberantasan Tindak Pidana Korupsi , Rapat Ke 5 Dengar Pendapat dengan Pakar Hukum, by Andi Hamzah (1999) at 37.

${ }^{41}$ Putusan Mahkamah Konstitusi Nomor 2-3/PUU-V/2007, Paragraf [3.26], halaman 430-431 
moderasi untuk mengartikan sikab yang diambil oleh MK, yaitu sikab mengambil jalan tengah antara kaum retensionisme dan kaum abolisionisme. ${ }^{42}$ Hal mana harus diakui bahwa masih sangat sulit bagi Indonesia untuk menghapuskan sanksi pidana mati atas dasar faktor karakterisik geografis, struktur kemasyarakatan, sistem hukum, dan lainsebagainya. Namun harus menjadi sebuah catatan, hukuman mati merupakan gradasi tertinggi dalam sanksi pemidanaan, yang mau tidak mau telah merampas hak untuk hidup seseorang. Maka diperlukan kesiapan dan kematangan sistem hukum secara utuh untuk dapat menerapkan sanski pidana mati ini di Indonesia.

\section{Norma-Subtantif Sanksi Pidana Mati dalam UU PTPK}

Penerapan sanksi pidana mati terhadap pelaku tindak pidana korupsi pertamakali diakomodir melalui ketentuan Undang Undang no 31 Tahun 1999 Tentang Pemberantasan Tindak Pidana Korupsi. Sebagaimana extra ordinary crime pada umumnya, korban atas tindak pidana korupsi bersifat menyebar (difusion victim) dan tidak dapat diketahui secara langsung (indirect victim). ${ }^{43}$ Lebih lanjut, tindak pidana korupsi dapat menimbulkan kemiskinan dalam suatu negara dan dapat melahirkan embrio embrio tindak pidana kejahatan lainnya. Maka munculah sebuah gagasan terhdapa pelaku tindak pidana korupsi untuk dapat diterapkan sanksi pidana mati.

Sanksi pidana mati dalam UU PTPK adalah salah satu dari beberapa tindak pidana khusus yang menerapkan sanksi pidana mati diluar ketentuan KUHP. Black law's dictionary memberikan arti sanksi pidana mati atau death penalty atau capital punishment sebagai kematian yang ditetapkan oleh negara sebagai hukuman untuk kejahatan serius, 44

Rumusan sanksi pidana mati dalam UU PTPK bersifat definite sentence, yaitu hakim dapat memilih berdasarkan pertimbangannya, apakah akan menjatuhkan sanksi pidana mati atau memilih sanksi pidana yang lainnya. Agar dapat dijatuhkan sanksi pidana mati terhadap koruptor, maka berdasarkan ketentuan Pasal 2 ayat (2)

\footnotetext{
${ }^{42}$ supra note 19 at $193-215$.

43 Warih Anjari, Penerapan Pidana Mati Terhadap Terpidana Kasus Korupsi (Masalah-Masalah Hukum, 2020) at 432-442.

44 Bryan Garner, Black's Law Dictionary (United State of America: West GroupSt.Paul Minn, 1999) as state-imposed death as punishment for a serious crime at 407.
} 
UU PTPK, tindak pidana korupsi harus dilakukan dalam keadaan tertentu. Namun demikian dalam perkembangannya konsep keadaan tertentu bukan diartikan kejahatan korupsi yang dilakukan pada waktu keadaan sebagaimana disebutkan dalam ketentuan pasal 2 ayat (2) Undang Undang No 31 Tahun 1999, namun ketentuan tersebut dirubah melalui Undang Undang No 20 Tahun 2001 yaitu menjadi "tindak pidana tersebut dilakukan terhadap dana-dana yang diperuntukkan bagi penanggulangan keadaan bahaya..."

Pergeseran pengertian tersebut bermakna, jika awalnya tindak pidana korupsi tersebut dilakukan pada saat "keadaan tertentu", maka dapat diberlakukan sanksi pidana mati. Sedangkan dalam penjelasan yang terbaru, hanya dikenakan sanksi pidana bila yang dikorupsi adalah dana yang digunakan untuk menanggulangi "keadaan tertentu". maka bilamana koruptor melakukan tindak pidana korupsi dalam keadaan Negara mengalami bencana nasional, namun yang dikorupsi bukan dana yang diperuntukan menanggulangi bencana nasional tersebut, maka terhadapnya tidak dapat dikenakan sanksi pidana mati. Hal tersebut memiliki kontradiksi dengan tujuan sanksi pidana mati dalam UU PTPK. Bilamana Negara berkomitmen menjadikan sanksi pidana mati sebagai instrument pemberantasan tindak pidana korupsi, maka dengan mengganti penjelasan dalam pasal 2 ayat (2) dalam Undang Undang No 20 Tahun 2001 merupakan salah satu kemunduran.

Selain keadaan-keadaan yang telah disebutkan diatas, terdapat kriteria "keadaan tertentu" yang dapat dibebankan sanksi pidana mati bagi pelakunya, yaitu terhadap pengulangan tindak pidana korupsi. Namun demikian, tidak terdapat kejelasan istilah pengulangan tindak pidana dalam kriteria keadaan tertentu sebagai pemberat tindak pidana. Sebagaimana disampaikan oleh Barda Nawawi Arif, selain tidak terdapat kejelasan batasan waktu pengulangan tindak pidana, juga tidak diberikan pengertian batasan pengulangan, misal saja terhadap perbuatan percobaan, pembantuan atau permufaktan jahat. ${ }^{45}$ Klausula pengulangan tindak pidana korupsi bersifat kabur (voge norm) yang menyebabkan ketidakpastian hukum. Selanjutnya menurut Barda Nawawi Arif untuk dapat ditetapkan pengulangan tindak pidana harus memperhatikan hal-hal berikut, yaitu: (i) syarat tenggang waktu pengulangan; dan (ii)

\footnotetext{
45 Barda Nawawi Arief, supra note 12 at 27.
} 
syarat perbuatan tindak pidana apa yang diulangi. ${ }^{46}$

Hal lain terdapat kelemahan dalam keberlakuan delik materiil dalam ketentuan Pasal 2 UU PTPK, misal saja terkait unsur merugikan keuangan negara. Merugikan keuangan negara diartikan sebagai perbuatan melawan hukum yang menyebabkan berkurangnya uang, atau barang (surat berharga) yang sudah pasti jumlahnya. ${ }^{47}$ Namun demikian, masih terdapat perbedaan persepsi terkait pengertian keuangan negaran. Undang Undang No 19 Tahun 2003 Tentang Badan Usaha Milik Negara dan Undang Undang no 40 Tahun 2007 tentang Perseroan Terbatas memisahkan keuangan negara dengan keuangan yang diolah oleh BUMN. Berbeda dengan hal tersebut, Undang Undang no 1 Tahun 2004 tentang Perbendaharaan Negara dan Undang Undang no 17 Tahun 2003 tentang keuangan Negara, menyebutkan bahwa penyertaan modal negara dalam BUMN, masuk dalam kategori keuangan negara. ${ }^{48}$ Ketidakpastian atas makna keuangan negara tersebut, memiliki konsekuensi sulitnya untuk menentukan terjadinya kerugian keuangan negara. Hal mana kerugian keuangan negara merupakan unsur pasal yang harus dibuktikan.

Beberapa hal yang menjadi kelemahan UU PTPK, harus dibaca bahwa Negara belum siap menerapkan sanksi hukuman mati bagi koruptor. Satu sisi ketidakastian hukum tersebut berpotensi pelanggaran HAM bagi koruptor. Kendati koruptor adalah penjahat, namun hukum lahir atas marwah keadilan. Negara harus bekerjakeras untuk memperbaiki sistem hukum, terutama terkait penerapan sanksi pidana mati terhadap koruptor.

\section{KESIMPULAN}

Pertama, karakteristik hukuman mati di Indonesia dalah bersifat moderasi (jalan tengah). Negara Indonesia tidak menghapuskan hukuman mati dalam sistem pemidanaan, namun demikian hukuman mati merupakan sanksi yang hanya diberlakukan terhadap pemberatan delik (gekwalificeerd delicten) atau terhadap tindak pidana yang bersifat khusus (special carakteristic). Hal lain terdapat beberapa

\footnotetext{
46 Barda Nawawi Arief, supra note 34 at 28.

47 Lihat ketentuan Pasal 1 ayat 22 Undang-Undang Nomor 1 Tahun 2004 tentang Perbendaharaan Negara

${ }^{48}$ Lihat Tesis Fina Rosalina, Pertanggungjawaban Pidana Bank Milik Negara atas kredit Bermasalah, yang berhasil dipertahankan pada tanggal 28 April 2018 di Universita Jember
} 
syarat yang memberatkan agar sanksi pidana mati tidak mudah untuk dijatuhkan.

Kedua, melalui sudut pandang sisi norm-subtantive, terdapat kelemahan dalam ketentuan UU PTPK sehingga menyebabkan sanksi pidana mati sulit untu dapat diterapkan terhadap koruptor kendati delict tersebut dilakukan dalam "keadaan tertentu". Beberapa kelemahan tersebut diantaranya, Pertama adalah tidak konsistennya Pemerintah dalam menerapkan istilah "keadaan tertentu", Kedua, Klausula pengulangan tindak pidana korupsi bersifat kabur (voge norm) Ketiga, belum terdapat kesepakatan tentang apa yang dimaksud dengan keuangan negara yang menyebabkan aparatur negara kesulitan dalam memberikan kepastian definisi dari kerugian keuangan negara .

\section{SARAN}

Pengakuan bahwa tindak pidana korupsi sebagai Serious Crime merupakan kesepaktan yang tidak dapat dipungkiri. Namun demikian, memaksakan penerapan sanksi pidana mati terhadap koruptor dalam ketidaksiapan Pemerintah berpotensi melahirkan pelanggaran HAM. Hal lain tidak diterapkan sanksi hukuman mati secara konsiten dapat meruntuhkan marwah hukum itu sendiri. Perlu komitmen kuat untuk memperbaiki sistem hukum terutama dalam sudut pandang sisi norm-subtantive, sebelum memberlakukan sanksi pidana mati.

Terdapat beberapa metode guna menekan kerugian keuangan negara sekaligus menimbulkan efek jera bagi pelaku korupsi, misal saja dapat dicontohkan dengan komitmen pemerintah untuk menerapkan sanksi memiskinkan koruptor dan penghapusan hak konstitusional bagi mantan koruptor untuk menduduki jabatan publik. Mengingat sanksi hukuman mati merupakan strata tertinggi dalam sistem pemidanaan, maka seharusnya negara memiliki metode lain sebagai alternative, sebelum menerapkan sanksi hukuman mati, misal saja yang telah disebutkan sebelumnya yaitu sanksi memiskinkan koruptor dan penghapusan hak konstitusional bagi mantan koruptor.

\section{DAFTAR PUSTAKA}

1 Ronny Hanitjo Soemitro, .Metode Penelitian Hukum Dan Jurimetri, Uakarta: Ghalia Indonesia, 1990), (Jakarta: Ghalia Indonesia, 1990).

164 HUKMY|Jurnal Hukum 
Andi Hamzah, Perbandingan Hukum Pidana Beberapa Negara (Jakarta: Sinar Grafika, 2008).

Barda Nawawi Arief, Bunga Rampai Hukum Pidana (Bandung: Citra Aditya Bakti, 1996).

-—- Masalah Pemidanaan Sehubungan dengan Perkembangan Delik-delik Khusus Dalam Masyarakat Modern (Bandung: Banacipta, 1982).

Bryan Garner, Black's Law Dictionary (United State of America: West GroupSt.Paul Minn, 1999).

Djoko Prakoso \& Nurwachid, Studi Tentang Pendapat-Pendapat Mengenai Efektivitas Pidana Mati di Indonesia Dewasa Ini (Jakarta: Ghalia Indonesia, 1984).

Edi Yunara, Korupsi dan Pertanggungjawaban Pidana Korporasi (Bandung: Citra Aditya Bakti, 2012).

Efryan R T Jacob, Pelaksanaan Pidana Mati Menurut Undang-Undang Nomor 2/Pnps/19641 (Lex Crimen, 2017).

Herbert L Packer, The Limits of the Criminals Sanctions (California: Stanford University Press, 1968).

JE Sahetapy, Pidana Mati dalam Negara Pancasila (Bandung: P.T. Citra Aditya Bakti, 2007).

Komisi Pemberantasan Tindak Pidana Korupsi, Dampak sosial Korupsi (Jakarta: Direktorat Pendidikan Dan Pelayanan Masyarakat Kedeputian Bidang Pencegahan, 2016).

Mei Susanto \& Ajie Ramdan, Kebijakan Moderasi Pidana Mati (Kajian Putusan Mahkamah Konstitusi Nomor 2-3/PUU-V/2007) (Jurnal Yudisial, 2017).

Mudzakkir, Perencanaan Pembangunan Hukum Nasional Bidang Hukum Pidana Dan Sistem Pemidanaan (Politik Hukum Dan Pemidanaan) (Departemen Hukum dan Hak Asasi Manusia Badan Pembinaan Hukum Nasional, 2008).

Peter Mahmud Marzuki, Penelitian Hukum (Jakarta: Kencana Predana Media Group, 2005).

Sudikno Mertokusumo \& Pitlo, Bab Bab Tentang Penemuan Hukum (Jakarta: PT Citra Aditya Bakti, 2013).

Warih Anjari, Penerapan Pidana Mati Terhadap Terpidana Kasus Korupsi (MasalahMasalah Hukum, 2020).

Wirjono Prodjodikoro, Asas-asas Hukum Pidana Indonesia (Bandung: PT. Eresco, 1989). HUKMY |Jurnal Hukum 165 
Kamus Bahasa Indonesia (Jakarta: Pusat Bahsa Departemen Pendidikan Indonesia, 2018).

Ervanda Rifqi Priambodo, et al, "Mengapa Korupsi Sulit Diberantas” (2021) Jurnal Ilmu Hukum Humaniora dan Ilmu Politik, Volume 1, Issue 1, September 2020, online: $<$ https://dinastirev.org/JIHHP>.

Muhammadiah, "Pidana Mati Menurut Hukum Islam Dan Hukum Positif Di Indonesia" (2019) Volume XI, No. 1 Komunike.

Nata Sukam, "Bangun Eksistensi Pidana Mati Dalam Sistem Hukum Indonesia” (2014) Universitas Atma Jaya Yogyakarta Fakultas Hukum Jurnal Ilmiah.

Roby Satya Nugraha, "Penjatuhan Hukuman Mati Terhadap Pelaku Tindak Pdiana Korupsi Berdasarkan Pasal 2 Ayat 2 Undang-Undang PTPK” (2020) Volume 06, Nomor 02 Pakuan Law Review.

Yohanes S Lon, "Penerapan Hukuman Mati di Indonesia dan Implikasi Pedagogisnya" Sarana Komunikasi Dosen dan Mahasiswa Volume 14, Nomor 12020 - CC-BYSA 4.0 License Kertha Wicaksana.

“KPK Tetapkan Mensos Juliari Batubara Tersangka Kasus Dugaan Suap Bansos” (2021) Kompas, online: <https://nasional.kompas.com/read/2020/12/06/02081481/kpk-tetapkanmensos-juliari-batubara-tersangka-kasus-dugaan-suap-bansos $>$.

Andi Hamzah, dalam Risalah Rapat Panitia Khusus Rancangan Undang Undang Pemberantasan Tindak Pidana Korupsi, Rapat Ke 5 Dengar Pendapat dengan Pakar Hukum, by Andi Hamzah (1999).

Dr Mahmud Mulyadi, SH, M Hum, dalam putusan Nomor 2-3/PUU-V/2007, by Dr Mahmud Mulyadi, SH, M Hum.

Menteri Kehakiman dan Jajarannya, Risalah Rapat Panitia Khusus Rancangan Undang Undang Pemberantasan Tindak Pidana Korupsi, (Rapat Kerja Ke-2), by Menteri Kehakiman dan Jajarannya (1999).

Metro Pekan Baru, Bupati Kudus Mengulang Korupsi Cabut Saja Hak Politik Korupsi, by Metro Pekan Baru (2021).

Juliari Batubara terima Rp32 Miliar ini dakwaan Jaksa (2021). 